\title{
Oxygen evolution in a hypersaline crust: in situ photosynthesis quantification by microelectrode profiling and use of planar optode spots in incubation chambers
}

\author{
Jana Woelfel ${ }^{1}$, Ketil Sørensen ${ }^{2}$, Mareike Warkentin $^{1}$, Stefan Forster $^{1}$, \\ Aharon Oren ${ }^{3}$, Rhena Schumann ${ }^{1, *}$ \\ ${ }^{1}$ University of Rostock, Institute for Biological Sciences, Albert- Einstein-Straße 3, 18059 Rostock, Germany \\ ${ }^{2}$ Danish Technological Institute, Kongsrang Allé 29, 8000 Aarhus, Denmark \\ ${ }^{3}$ The Institute of Life Sciences, and the Moshe Shilo Minerva Center for Marine Biogeochemistry, \\ The Hebrew University of Jerusalem, Jerusalem, Israel
}

\begin{abstract}
Net primary production and respiration were estimated in a hypersaline cyanobacterial mat colonizing a gypsum crust in the Eilat salterns, Israel. Two different approaches were used: in situ microprofiling with Clark-type $\mathrm{O}_{2}$ sensors and application of optode sensor spots in incubation chambers. The net $\mathrm{O}_{2}$ release rates of the mat phototrophs was high, with a maximum of $3.4 \mathrm{nmol} \mathrm{O}_{2}$ $\mathrm{cm}^{-2} \mathrm{~min}^{-1}$ measured by microprofiling and $4.4 \mathrm{nmol} \mathrm{O}_{2} \mathrm{~cm}^{-2} \mathrm{~min}^{-1}$ determined in the incubation chambers. The upper 2 layers of the mat as well as the overlying water quickly became $\mathrm{O}_{2}$ saturated during the day. The respiration of the whole gypsum crust was also very intensive and corresponded to the $\mathrm{O}_{2}$ produced by photosynthesis on a diurnal basis, which prevented most of the evolved $\mathrm{O}_{2}$ from reaching the water. The results presented show that optode sensor spots are useful tools providing additional information about export and photosynthetic production rates of $\mathrm{O}_{2}$ in hypersaline microbial mats.
\end{abstract}

KEY WORDS: Hypersaline - Gypsum crust • Microbial mat - Net production and respiration · Microelectrode $\cdot$ Optode

\section{INTRODUCTION}

Multi-pond solar salterns, used worldwide for salt production along the coasts in tropical and subtropical areas, are interesting environments to study limitations of marine benthic and planktonic photosynthetic processes. With a gradient of salt concentrations, from seawater to $\mathrm{NaCl}$ saturation, characteristic salt-adapted communities of phototrophic microorganisms can be found (Oren 2009 , this Special Issue). When evaporation of seawater has proceeded to 3-4 times the original salinity (150 to $250 \mathrm{PSU})$, the solubility of calcium sulfate is exceeded and gypsum $\left(\mathrm{CaSO}_{4} \cdot 2 \mathrm{H}_{2} \mathrm{O}\right)$ precipitates to the bottom of the ponds and forms crusts of many centimeters thickness. Characteristically laminated communities of phototrophic microorganisms are found in these crusts: an upper layer consisting of carotenoid-rich orangecoloured Cyanobacteria of the Halothece-Aphanothece group (Garcia-Pichel et al. 1998), followed by a darkgreen layer of Phormidium-type filamentous Cyanobacteria and, underneath, a purple layer of Halochromatium and Ectothiorhodospira/Halorhodospira, which performs anoxygenic photosynthesis with sulfide as electron donor, derived from sulfate reduction in the anaerobic layers below. The arrangement of gypsum crystals allows the light to penetrate deep into the crust, so that active photosynthesis may occur down to depths of several centimeters. Such layered phototrophic communities have been described from different salterns worldwide, e.g. in the south of France (Caumette et al. 
1994), in Spain (Thomas 1984) and in Israel (Canfield et al. 2004, Sørensen et al. 2004, 2005, Ionescu et al. 2007, Oren et al. 2009).

Ambient salinity is one of the key factors determining the photosynthetic rates of the cyanobacterial community in the hypersaline gypsum crusts. A salinity decrease from 230 to $200 \mathrm{~g} \mathrm{l}^{-1}$ in such a crust in Eilat increased $\mathrm{O}_{2}$ production from $<2$ to $8-9 \mu \mathrm{mol} \mathrm{O}_{2} \mathrm{l}^{-1}$ $\mathrm{min}^{-1}$ as measured by a microelectrode (Canfield et al. 2004). However, our overall understanding of the photosynthetic activities in such benthic gypsum crusts and the environmental factors governing them is still extremely limited.

The measurement of benthic microbial primary production is methodologically difficult, and many different techniques have been used. The benthic $\mathrm{O}_{2}$ exchange rate represents the most widely used proxy for quantifying respiration and primary production of marine sediments. These investigations represent a challenge in resolving variations on temporal and spatial scales covering several orders of magnitude (Glud 2008). To overcome these obstacles, $\mathrm{O}_{2}$ sensors (electrochemical or optical) with a higher spatial and temporal resolution have been applied in situ to obtain $\mathrm{O}_{2}$ profiles within sediments (e.g. Revsbech et al. 1980a, 1980b, 1983, Kühl et al. 1996), from which benthic $\mathrm{O}_{2}$ exchange rates were then estimated. Another problem is the high degree of horizontal patchiness of the biomass as well as its activities. The latter interferes especially with $\mathrm{O}_{2}$ profiles when using a 1-dimensional approach: the profiles are measured at a single or several distinct positions with a high vertical resolution, but the horizontal resolution within the sediment area is limited. Thus, the extrapolation of such results to larger areas $\left(\mathrm{mm}^{2}\right.$ to $\mathrm{m}^{2}$ scale) is not always simple. Besides many ex situ approaches, in situ measurements have been carried out in benthic chambers in which primary production was estimated from the $\mathrm{O}_{2}$ evolution over the sediment (e.g. Cahoon \& Cooke 1992, Longphuirt et al. 2007, Glud et al. 2008). Such chambers integrate the patchiness corresponding to the covered sediment area, but do not resolve benthic production to the productive sediment layer(s).

$\mathrm{O}_{2}$ microelectrodes have also been used in gypsum crusts that are difficult to penetrate, e.g. in the Salins-deGiraud, France (Caumette et al. 1994) and in the salterns of the Israel Salt Company in Eilat (Canfield et al. 2004). Overall photosynthesis rates in the Eilat gypsum crust were much lower than those typically found in organicrich microbial mats at lower salinities. However, on a per cell-volume basis, the rates were comparable. Benthic chambers equipped either with electrochemical sensors or optodes have rarely been applied in situ to gypsum crusts so far, as they cannot be drilled into the upper sediment layers to fix the chambers to the sediment surface.
Optical $\mathrm{O}_{2}$ indicators exhibit the highest sensitivity at low $\mathrm{O}_{2}$ concentrations and are not affected by hydrogen sulfide (Kühl \& Polerecky 2008), which is often present in sediments. Furthermore, optical sensors do not consume $\mathrm{O}_{2}$ and are thus best suited for long-term measurements at very low initial $\mathrm{O}_{2}$ concentrations. Therefore, many studies of benthic microbial communities (e.g. reviewed in Glud et al. 1999, Kühl \& Polerecky 2008) have been carried out using such optical sensor foils, ranging from $\mu \mathrm{m}$ to several $\mathrm{cm}$ in diameter, in combination with new imaging methods for instantaneous mapping of the distribution and dynamics of $\mathrm{O}_{2}$ concentrations and photosynthetic activity. However, the mechanical stability of optodes in the form of sensor tips is not yet robust enough for sandy sediments and crusts. The black coating protecting the optode from scattered light is easily scratched off during profiling.

Planar $\mathrm{O}_{2}$ optical sensor spots placed within (benthic) incubation chambers allow the determination of the export rate of $\mathrm{O}_{2}$ from a defined sample area into the overlying water (net $\mathrm{O}_{2}$ release). Further advantages of this approach are the easy handling and robustness under field conditions, the possibility of non-destructive sediment measurements and independence of the $\mathrm{O}_{2}$ signal on water flow.

The aim of the present study was to quantify $\mathrm{O}_{2}$ production and consumption in the hypersaline gypsum crust of the Eilat salterns using 2 different approaches. Net production and respiration rates calculated from micro-profiles were used to quantify organism activity (net photosynthesis) within the mat layers. However, the primary focus was net $\mathrm{O}_{2}$ release into the overlying water as a proxy for benthic community production. The use of optode sensor spots for hypersaline and warm environments (low initial $\mathrm{O}_{2}$ concentrations) is evaluated and the incubation chamber setup and experimental design are critically discussed. Our results demonstrate that optode sensor spots can be successfully applied to measurements of primary production in crusts under hypersaline conditions.

\section{MATERIALS AND METHODS}

Sampling site. A stable and thick gypsum crust from one pond (Pond 103) of the saltern system of Eilat, Israel, was investigated. The salterns have been in operation since 1980 and are fed with oligotrophic seawater from the Gulf of Aqaba (Eilat). Nitrate concentrations in the surface waters of the Gulf of Aqaba are $<1 \mu \mathrm{mol} \mathrm{NO}{ }_{3}^{-}{ }^{-1}$ throughout most of the year (April to November), but may increase to about $3.5 \mu \mathrm{mol} \mathrm{NO}{ }_{3}^{-}$ $\mathrm{l}^{-1}$ at the end of the winter (Lindell \& Post 1995). Phosphate concentrations are in the $\mathrm{nM}$ range (Stihl et al. 
2001). Since 1997, brine concentrate from the seawater desalination plant in Eilat has been added to the evaporation ponds as well. Information on the types of phototrophic microorganisms in the crust studied was given by Prášil et al. (2009, this Special Issue). The rich bird life in the salterns may also add nutrients to the ponds. Average water depth in the ponds is 40 to $50 \mathrm{~cm}$.

Environmental conditions. Weather data were obtained from the Israel National Monitoring of the Gulf of Eilat (www.meteo-tech.co.il). Hydrological data at sampling times are summarized in Table 1. The gypsum crusts were composed of a $5 \mathrm{~mm}$ orange layer at the top, followed by a second ca. 10 to $15 \mathrm{~mm}$ white layer, followed by a third 3 to $5 \mathrm{~mm}$ blue-green layer and a fourth, 2 to $3 \mathrm{~mm}$ thick purple layer. At the bottom of the crust, a black sediment layer was found that was not included in the in situ investigation of the separate layers, but which could not be excluded completely from the whole core incubations. Water content of whole cores and of each separate layer was estimated from crushed samples (for whole cores: 37 to $74 \mathrm{~g}$ fresh weight [FW], for separate layers: 4 to $8 \mathrm{~g} \mathrm{FW}$ ) as weight loss after drying.

Nutrients. Immediately after collection, water samples (ca. $50 \mathrm{ml}$ ) were filtered through $0.2 \mu \mathrm{m}$ membrane filters or, in case of very mucous-rich samples, through $0.45 \mu \mathrm{m}$ membranes, and the filtrates were kept cool at $5^{\circ} \mathrm{C}$ until analysis. These sterile, particlefree samples were diluted with distilled water to seawater salinity before photometric analysis. Nitrate, nitrite and phosphate were assayed using a Technicon Traacs 800 autoanalyzer. For nitrate and nitrite, we used the procedure described by Garside \& Garside (1993). In addition, colorimetric analyses of ammonium, nitrite, nitrate and phosphate were performed manually. Appropriate tests were made to ensure that the salts still present did not significantly interfere with the assays, and, if necessary, corrections were made for the salt effect (Coleman \& White 1993). Ammonium was assayed using the phenol-hypochlorite method developed by Solórzano (1969). Nitrate, nitrite and phosphate were assayed as outlined by Strickland \& Parsons (1972).

Microelectrode profiles for net production. Intact pieces of crust (approximately $20 \times 20 \mathrm{~cm}$ area and $10 \mathrm{~cm}$ deep) were sampled and transported to the laboratory, where they were incubated outside in an aquarium containing water from Pond 103 (Expt $A_{\text {; }}$ Tables $1 \& 2$ ). The aquarium was placed in a seawaterflooded basin that was temperature stable at 21 to $22^{\circ} \mathrm{C}$. Inside the aquarium, the sides of the crust were supported by sand to preserve its shape during measurements and to prevent light from entering from the sides. Profiles were measured using Clark-type microsensors (Unisense) with guard cathodes (Revsbech 1989). Calibrations were performed in aerated brine from each pond (100\% atmospheric saturation) and in a $0.1 \mathrm{M}$ ascorbate $+0.1 \mathrm{M} \mathrm{NaOH}$ solution $(0 \%$ oxygen) according to the manufacturer's instructions. The zero-oxygen value was also confirmed during profiling when the electrode reached the anoxic zone of the crust. The electrode was inserted in a $5 \mathrm{~cm}$ long and $0.8 \mathrm{~mm}$ thick (outer diameter) hypodermic needle (Canfield et al. 2004). Profiles were measured every $30 \mathrm{~min}$ in the morning from 5:30 to $10: 30$ and in the afternoon from 16:00 to 19:00. The sensor required about $30 \mathrm{~s}$ to equilibrate at each new depth, and it took approximately $15 \mathrm{~min}$ to measure each profile. To decrease the risk of breaking the sensors, 3 to 4 successive profiles were measured in the same location instead of moving the sensor before each new profile. The measurements were thus performed in a total of 4 different locations (Table 2). The sensors were controlled using a micromanipulator and a PC-controlled motor unit. Data collected from the picoamperometer were continuously collected on the PC using Sensor Trace PRO v1.9 software (Unisense). Diffusive vertical

Table 1. Environmental conditions during the experiments on gypsum crust $\mathrm{O}_{2}$ evolution: density of the brine in $\mathrm{g}^{-3}{ }^{-3}$, water temperature, nutrients (a: ammonium, n: nitrate, p: phosphate) and average daily solar radiation. Incubation water for experiments was taken during sampling, from the filtered water used for the incubations, and from the respective experiments: $(\mathrm{A}) \mathrm{O}_{2}$ profiles on intact crusts; (B1) $\mathrm{O}_{2}$ evolution of separate layers without nutrient enrichment and (B2) with nutrient enrichment; (C1) daily $\mathrm{O}_{2}$ evolution over whole cores of crusts at in situ solar radiation and (C2) partly shaded

\begin{tabular}{|c|c|c|c|c|c|}
\hline Date & $\begin{array}{l}\text { Brine } \\
\text { density }\end{array}$ & $\begin{array}{l}\text { Water temperature } \\
\qquad\left({ }^{\circ} \mathrm{C}\right)\end{array}$ & $\begin{array}{l}\text { Nutrients } \\
\left(\mu \mathrm{mol} 1^{-1}\right)\end{array}$ & $\begin{array}{l}\text { Solar radiation } \\
\quad\left(\mathrm{W} \mathrm{m}^{-2}\right)\end{array}$ & Samples \\
\hline 01 April & 1.106 & 28 & & 298 & Gypsum crust \\
\hline 02 April & & & & 303 & Gypsum crust \\
\hline \multirow[t]{2}{*}{03 April } & 1.109 & & $\begin{array}{c}\text { a: } 0-0.5 \\
\mathrm{n}: 3.1-4.6\end{array}$ & 306 & Incubation water \\
\hline & & & p: $3.3-3.9$ & & B1, C1 \\
\hline 04 April & & & & 253 & A \\
\hline 05 April & & & & 289 & $\mathrm{~B} 2, \mathrm{C} 2$ \\
\hline
\end{tabular}


Table 2. Treatments and microprofiles for each experiment

\begin{tabular}{|c|c|c|c|c|}
\hline Expt & Description & Light conditions & Samples/treatments & No. of replicates \\
\hline A & In situ microprofiles & $\begin{array}{l}\text { Morning and evening solar } \\
\text { radiation }\end{array}$ & $\begin{array}{l}15 \text { profiles measured in } \\
4 \text { consecutive holes }\end{array}$ & n.d. \\
\hline B1 & $\begin{array}{l}\text { Net } \mathrm{O}_{2} \text { export under in situ } \\
\text { solar radiation }\end{array}$ & $\begin{array}{l}7 \text { intervals over } 24 \mathrm{~h} \\
\text { (total } 40 \mathrm{~h} \text { ) }\end{array}$ & 1 & 3 \\
\hline B2 & $\begin{array}{l}\text { Net } \mathrm{O}_{2} \text { export of fully exposed and } \\
\text { shaded cores }\end{array}$ & $\begin{array}{l}5 \text { intervals over } 24 \mathrm{~h} \\
\text { (total } 29 \mathrm{~h} \text { ) }\end{array}$ & 2 & 2 for each treatment \\
\hline $\mathrm{C} 1$ & $\mathrm{O}_{2}$ production of all 4 separate layers & 1 dark and 4 light steps & 4 & n.d. \\
\hline $\mathrm{C} 2$ & $\begin{array}{l}\mathrm{O}_{2} \text { production of orange and blue-green } \\
\text { layers with N and NP additions }\end{array}$ & 1 dark and 3 light steps & 4 & n.d. \\
\hline
\end{tabular}

fluxes of $\mathrm{O}_{2}$ across the crust-water interface were estimated using Fick's first law of diffusion

$$
J=-\Phi \times D \times \mathrm{d} C / \mathrm{d} x
$$

In Eq. (1), $J$ is the net diffusive flux, $\Phi$ is the tortuosity, $D$ is the diffusion coefficient of $\mathrm{O}_{2}$ in the crust, which depends on salinity, temperature and porosity, and $\mathrm{d} C / \mathrm{d} x$ is the concentration gradient of $\mathrm{O}_{2}$ with depth. $\mathrm{O}_{2}$ fluxes were estimated from the $\mathrm{O}_{2}$ concentration gradient in the boundary layer at and immediately above the crust surface. Here, effects from tortuosity and porosity are negligible and the diffusion coefficient equals that of water at the same temperature and salinity. The distribution of $\mathrm{O}_{2}$ in the crust was measured at different times during the day. The net $\mathrm{O}_{2}$ diffusion across the crust-water interface was estimated from each of the measured profiles using Eq. (1). The net rate of $\mathrm{O}_{2}$ accumulation in the crust was calculated by estimating and comparing the total $\mathrm{O}_{2}$ content of the crust at different times, accounting for a porosity of 0.5 and based on the depth-integrated concentration profiles. Furthermore, net $\mathrm{O}_{2}$ production was estimated as the sum of accumulation in the crust and upward flux across the interface. Downward $\mathrm{O}_{2}$ flux into the crust was neglected as downward concentration gradients were generally lower than upward gradients. Porosity $(\sim 0.5)$ and tortuosity in the crust would additionally decrease downward fluxes calculated to $<25 \%$ of the net $\mathrm{O}_{2}$ diffusion across the interface.

$\mathrm{O}_{2}$ measurements with planar optode spots. The planar $\mathrm{O}_{2}$ sensor spots $(\varnothing: 5 \mathrm{~mm})$ (PreSens) were glued to the inner walls of the incubation chambers. Molecular oxygen quenches the luminescence of the dye immobilized in the $\mathrm{O}_{2}$-permeable matrix of the sensor spots. This fluorescence signal decrease was measured noninvasively by a $1 \mathrm{~m}$ (for separate layers) or a $10 \mathrm{~m}$ (for whole core measurements) long glass fiber through the Plexiglas wall of the chamber. The measuring accuracy of planar sensor spots is around $\pm 0.5 \%$ at $85.0 \mu \mathrm{mol} \mathrm{O}_{2}$ $\mathrm{l}^{-1}$ and $\pm 5 \%$ at $2.8 \mu \mathrm{mol} \mathrm{O} \mathrm{O}^{-1}$ (PreSens, cited in Warkentin et al. 2007, p. 6724).
Since the conversion matrix of the measured signal into saturation and concentration was not applicable for salinities $>40$ PSU, the signal was calibrated against the chemical volumetric determination of $\mathrm{O}_{2}$ concentration (Winkler 1888) in 164 PSU (1.109 $\mathrm{g} \mathrm{O}_{2}$ $\mathrm{ml}^{-1}$ ) water with the help of the Stern-Volmer relationship.

$$
\frac{I_{\mathrm{f}}^{0}}{I_{\mathrm{f}}}=1+k_{\mathrm{q}} \tau_{0} \cdot[\mathrm{Q}]
$$

In Eq. (2), $I^{0}{ }_{\mathrm{f}}$ is the intensity of fluorescence without a quencher, $I_{\mathrm{f}}$ is the intensity of fluorescence with a quencher, $k_{\mathrm{q}}$ is the quencher rate co-efficient, $\tau_{0}$ is the fluorescence lifetime of the dye without a quencher present and [Q] is the concentration of the quencher. From that, we calculated the factor $\left(k_{\mathrm{q}} \cdot \tau_{0}\right)$ by fitting concentrations against phases (Fig. 1). This factor and maximal phase $I_{\mathrm{f}}^{0}$ were used to convert all later optode measurements into $\mathrm{O}_{2}$ concentrations.

Up to 20 min of initial data were omitted from the analyses or not recorded because of phase changes

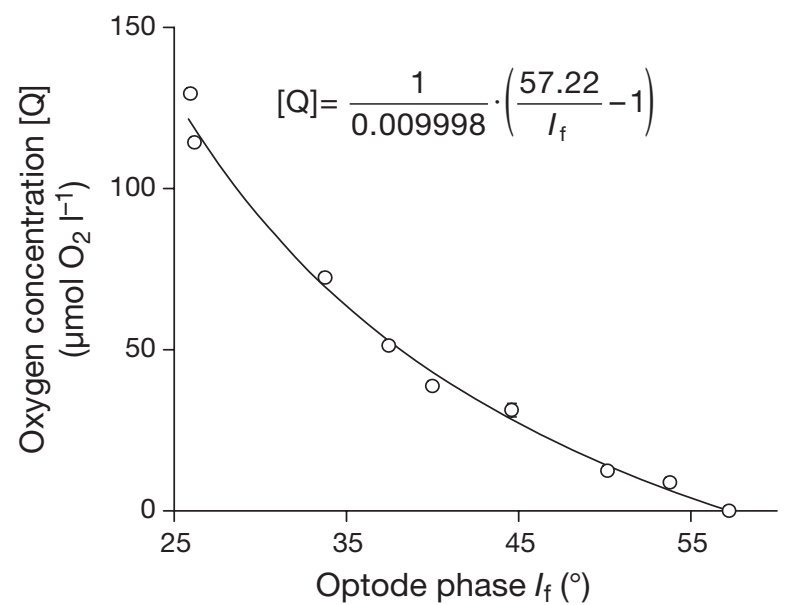

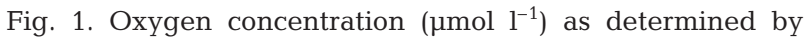
Winkler titration and optode phase signal $\left({ }^{\circ}\right)$ in $\mathrm{NaCl}$ solutions (164 PSU) of different oxygen saturations provided by nitrogen bubbling at $21^{\circ} \mathrm{C}$. Trend from fitting concentrations [Q] against phases $I_{\mathrm{f}}$ after the Stern-Volmer equation (Eq. 2) (factor of 0.009998 is $k_{\mathrm{q}} \times \tau_{0}$ and $I_{\mathrm{f}}^{0}=57.22$ ) 
between sample and the spot and/or chamber due to temperature equilibration. The release rates were calculated from the decrease or increase of $\mathrm{O}_{2}$ in the supernatant water volume during dark (called respiration) and light treatments (benthic $\mathrm{O}_{2}$ release or, in case of separate layers, net production). These rates were converted into fluxes driven by the core or layer areas or chl a contents, respectively. The conversion of $\mathrm{O}_{2}$ into $\mathrm{C}$ units was done with a factor of 1 (1 C per 1 $\mathrm{O}_{2}$ ), assuming carbohydrate to be the main photosynthesis product.

Incubation setup to determine net $\mathrm{O}_{2}$ export of specific layers. Two methodological approaches, both based on planar $\mathrm{O}_{2}$ sensor spots, were used to determine net $\mathrm{O}_{2}$ export of (1) whole crust cores and (2) separate layers of the microbial mat (Table 2). For (1), the spots (1 per core) were situated in the upper part of 3 replicate chambers, approximately at a distance of 10 to $11 \mathrm{~cm}$ from each other. For (2), the spots (1 per layer) were positioned at $2 \mathrm{~cm}$ distance to each sectioned layer in 4 replicate chambers. All chambers were filled completely with water from Pond 103, from which $\mathrm{O}_{2}$ oversaturation was removed by bubbling with $\mathrm{N}_{2}$, and sealed air-tight.

For (1), net $\mathrm{O}_{2}$ release over $>24 \mathrm{~h}$ was recorded from whole cores cut from crusts sampled on 1 April and exposed to in situ irradiation at constant temperature conditions $\left(21\right.$ to $22^{\circ} \mathrm{C}$ ) on 3 and 5 April (Expts B1 \& B2). Up to three replicate air-tight plexiglass incubation chambers (185 mm height, inner diameter $40 \mathrm{~mm}$, $232.5 \mathrm{ml}$ ) with whole cores contained a $3 \mathrm{~cm}$ magnetic stirring cross, which mixed potential $\mathrm{O}_{2}$ gradients in the water column for $10 \mathrm{~min}$ prior to $\mathrm{O}_{2}$ readings. The stirring cross rotated at 6 to $7 \mathrm{rpm}$ and was driven by an external rotating magnet. We frequently noticed the accumulation of bubbles at the mat surface within the core tubes. After stirring, most bubbles disappeared from the water phase. The chambers were enveloped in dark foil up to the top 2 to $5 \mathrm{~mm}$ of the crust to avoid irradiation of the core sides. Approximately 10 manual readings were taken per measurement with an average deviation of $2.1 \%$.

For (2) (Expts C1 \& C2), cores from the same gypsum crust were sliced into 4 layers using a knife and spatula, and measured separately. The top orange layer was obtained as one piece (approximately an ellipse of $30 \times 35 \mathrm{~mm}$ ) and the 3 other layers (white, blue-green and purple) broke down into ca. 5 to $10 \mathrm{~mm}$ pieces of gypsum crystals with attached microorganisms. All pieces were transferred immediately into plexiglass incubation chambers $(40 \mathrm{~mm}$ inner diameter, $50 \mathrm{~mm}$ height, $62.8 \mathrm{ml}$ ). The intact top layer was up to $10 \mathrm{~mm}$ thick and the gypsum particles formed several $\mathrm{mm}$ deep layers. Layer volume was estimated and included as reference parameter. Gas bubbles attached to the gypsum particles were removed with a spatula and only bubble free samples were incubated.

All chambers (Expts B1, B2, C1 \& C2) were pre-incubated in a $26^{\circ} \mathrm{C}$ water bath in darkness for a minimum of $1 \mathrm{~h}$, which was close to the in situ temperature. After that, a dark incubation period of 3 to $3.5 \mathrm{~h}$ was started, during which $\mathrm{O}_{2}$ concentrations in the 4 incubation chambers were read at least twice over a time span of $>10$ min. After that, up to 4 different light treatments were applied. All $\mathrm{O}_{2}$ measurements were taken over a duration of ca. $10 \mathrm{~min}$, providing $\mathrm{O}_{2}$ values every $5 \mathrm{~s}$. The lowest photon flux (PFD) of $20 \mu \mathrm{mol}$ photons $\mathrm{m}^{-2}$ $\mathrm{s}^{-1}$ was achieved by shading the fluorescent lamps (Philipps TLD 15W 54) with 3 layers of black gauze, and PFDs of 30, 40 and $80 \mu \mathrm{mol}$ photons $\mathrm{m}^{-2} \mathrm{~s}^{-1}$ were obtained by 2 or 1 layer(s) of gauze or without shading, respectively. Nutrients $[3 \mu \mathrm{M}$ phosphate $(+\mathrm{P})$ or $3 \mu \mathrm{M}$ phosphate and $48 \mu \mathrm{M}$ nitrate (+NP)] were added in a follow-up experiment, in which only the third (bluegreen) phototrophic layer was investigated.

Biomass parameters. Chlorophyll a (chl a) was extracted with $90 \%$ acetone $\left(12 \mathrm{~h}\right.$ in darkness at $\left.5^{\circ} \mathrm{C}\right)$ from ca. 0.5 to $2 \mathrm{~g}$ wet weight (ww) of homogenized crust particles retrieved from the incubation chambers after the $\mathrm{O}_{2}$ measurements. Afterwards, the centrifuged supernatant was determined according to Jeffrey \& Humphrey (1975) except for the blank absorption, which had to be measured at $850 \mathrm{~nm}$ due to interference by bacteriochlorophylls at $750 \mathrm{~nm}$ (Oren et al. 1995). The deviation of chl a per $\mathrm{g}$ ww of crust for triplicate extractions per sample was highest in the orange layer (14 to $109 \%$ ), because the gypsum particles were rather large (up to $7 \mathrm{~mm}$ ) and hard to homogenize. The other layers and whole cores had a better reproducibility with an average of 33 and $14 \%$, respectively. For the estimation of the total organic carbon (TOC) concentration and the molar ratio of carbon to nitrogen ( $\mathrm{C}: \mathrm{N}$ ratio) within the crust, ca. $150 \mathrm{mg}$ of dry material were measured (after inorganic carbon was expelled with a $10 \% \mathrm{HCl}$ solution) in an element analyzer (Vario EL, Elementar) according to Verardo et al. (1990).

\section{RESULTS}

\section{Environmental conditions}

Pond 103 had a salinity of 157 to 164 PSU and a water temperature of ca. $28^{\circ} \mathrm{C}$ in the afternoon when samples were collected. Nitrate and phosphate concentrations in the water overlaying the crust were 3 to $5 \mu_{\mathrm{mol} \mathrm{NO}}{ }^{-}$ $\mathrm{l}^{-1}$ and 3 to $4 \mu \mathrm{mol} \mathrm{PO}_{4}^{+} \mathrm{l}^{-1}$, respectively (Table 1 ). Average daily solar radiation was $285 \mathrm{~W} \mathrm{~m}^{-2}$ in late March/early April. While whole core incubations 
(Expts B1 \& B2) on 3 and 5 April were carried out on days with this average radiation, which is based on almost cloud-free days, in situ microprofiling (Expt A) was carried out on a day with radiation levels ca. $10 \%$ below average, due to many hours of cloud cover during the incubation.

\section{Microbial biomass in the gypsum crusts}

Whole cores had a water content of 20 to $26 \%$. The TOC content was rather low with 0.16 to $0.20 \%$ of dry mass. The blue-green (third) layer was the only one with an organic carbon content slightly above average with up to $0.28 \%$ of dry mass. The molar C:N ratio was 7.5 to 8.9 within the 4 upper separate layers, while the 2 phototrophic layers (first: orange; third: blue-green) had values at the upper end of range. In whole cores including a black-grey (fifth) layer, molar C:N ratios of 6.3 to 9.5 according to Hillebrand (1999) did not indicate a severe nitrogen limitation of the microphytobenthos either. Chl a contents increased with depth from $0.7-1.9$ to $7.5-11 \mu \mathrm{gg}$ dry weight ${ }^{-1}$ in the purple (fourth) layer. The high amount of chl $a$ in the purple layer may only partly be attributed to material derived from the green layer above, since much care was taken to avoid contamination when separating the layers. Instead, it may have been derived from degrading inactive cyanobacterial biomass.

\section{Net $\mathrm{O}_{2}$ production within the crust}

Fig. 2 shows examples of $\mathrm{O}_{2}$ profiles measured in the crust from Pond 103. There was a small peak of $\mathrm{O}_{2}$ at about $3 \mathrm{~mm}$ in the profile from 05:30 am, indicating that respiration during the night did not entirely exhaust the pool of $\mathrm{O}_{2}$ generated during the day. Primary production commenced at sunrise, and the net flux across the crust-water interface as estimated from the measured $\mathrm{O}_{2}$ release at the surface (Eq. 1; Table 3) was reversed $1 \mathrm{~h}$ later. Estimated exchange rates reached about $0.06 \mathrm{nmol} \mathrm{O}_{2} \mathrm{~cm}^{-2} \mathrm{~s}^{-1}$ around noon and decreased during the afternoon. At sunset, the estimated flux was again close to zero. The net rates of $\mathrm{O}_{2}$ accumulation within the crust in the morning and $\mathrm{O}_{2}$ consumption in the afternoon were generally at least an order of magnitude higher than the estimated rates of diffusion across the crust-water interface (Table 3), indicating that a large proportion of the $\mathrm{O}_{2}$ produced by Cyanobacteria in the orange and green layers was retained and consumed within the crust. The profiles indicated that $\mathrm{O}_{2}$ diffused at a rate of about $0.008 \mathrm{nmol}$ $\mathrm{O}_{2} \mathrm{~cm}^{-2} \mathrm{~s}^{-1}$ from the water phase into the upper ca. $2 \mathrm{~mm}$ of the crust during the night.

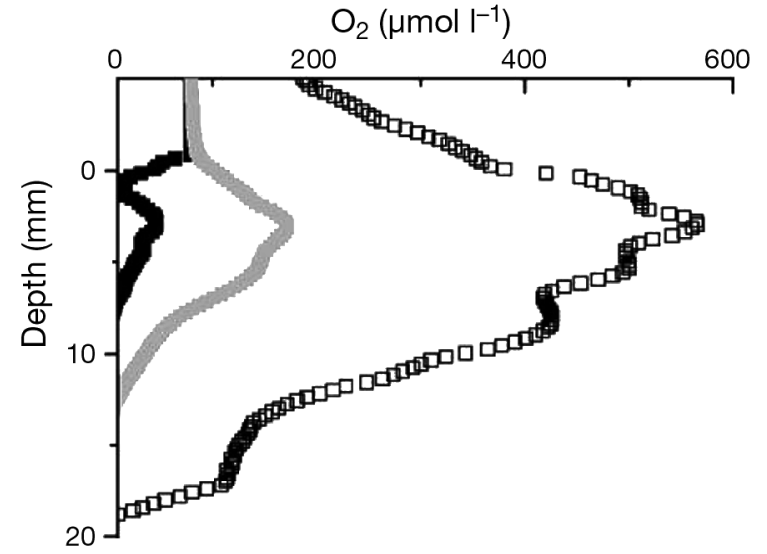

Fig. 2. Oxygen profile in a crust from Pond 103 measured in the morning on 4 April. Measurements taken at $(\boldsymbol{C})$ 05:30, $(\square)$ 06:30, (口) 09:30

\section{$\mathrm{O}_{2}$ release from whole cores and production in separate layers}

Incubations of whole cores started in the early evening hours at $\mathrm{O}_{2}$ concentrations of 83 to $103 \mu \mathrm{mol} \mathrm{O}_{2} \mathrm{l}^{-1}$ in the supernatant water (Fig. 3). During the night, $\mathrm{O}_{2}$ decreased to almost a quarter of the initial concentration in the water phase in some chambers. While $\mathrm{O}_{2}$ concentrations were still very low at 11:00 am, they started to increase around 12:00 and reached maxima of ca. $122 \mu \mathrm{mol} \mathrm{O} \mathrm{I}^{-1}$ late in the afternoon, ca. $24 \mathrm{~h}$ after incubations started. Calculating changes in $\mathrm{O}_{2}$ concentration from one measuring time to the next, maximum respira-

Table 3. $\mathrm{O}_{2}$ content, $\mathrm{O}_{2}$ release $\left(\mathrm{O}_{2}\right.$ exchange) rate, and net $\mathrm{O}_{2}$ production calculated from microprofiles measured on 4-5 April 2008. $\mathrm{O}_{2}$ content is the depth-integrated $\mathrm{O}_{2}$ profile, accounting for porosity $(0.5 \mathrm{vol} / \mathrm{vol})$, from the crust-water interface down to the $\mathrm{O}_{2}$ depletion depth; $\mathrm{O}_{2}$ exchange rate was calculated from the $\mathrm{O}_{2}$ gradient in the boundary layer neglecting porosity and tortuosity; net $\mathrm{O}_{2}$ production $=\mathrm{O}_{2}$ content $+\mathrm{O}_{2}$ exchange rate

\begin{tabular}{|cccc|}
\hline Time & $\begin{array}{c}\mathrm{O}_{2} \text { content } \\
\left(\mathrm{nmol} \mathrm{cm}^{-2}\right)\end{array}$ & $\begin{array}{c}\mathrm{O}_{2} \text { release rate } \\
\left(\mathrm{nmol} \mathrm{cm}^{-2} \mathrm{~s}^{-1}\right)\end{array}$ & $\begin{array}{c}\mathrm{Net}_{2} \text { production } \\
\left(\mathrm{nmol} \mathrm{cm}^{-2} \mathrm{~s}^{-1}\right)\end{array}$ \\
\hline $05: 30$ & 139 & -0.008 & \\
$06: 00$ & 322 & -0.001 & 0.10 \\
$06: 30$ & 673 & 0.004 & 0.20 \\
$07: 00$ & 1238 & 0.007 & 0.32 \\
$07: 30$ & 1936 & 0.018 & 0.41 \\
$08: 00$ & 2153 & 0.016 & 0.14 \\
$08: 30$ & 2476 & 0.018 & 0.20 \\
$09: 00$ & 3053 & 0.016 & 0.34 \\
$09: 30$ & 3250 & 0.018 & 0.13 \\
$10: 30$ & 3360 & 0.057 & 0.09 \\
$16: 00$ & 2099 & 0.048 & -0.02 \\
$16: 30$ & 1631 & 0.023 & -0.24 \\
$17: 20$ & 1176 & 0.026 & -0.13 \\
$18: 00$ & 1106 & 0.007 & -0.02 \\
$19: 00$ & 397 & 0.010 & -0.19 \\
\hline
\end{tabular}


tion rates were $-0.056 \mathrm{nmol} \mathrm{O}_{2} \mathrm{~cm}^{-2} \mathrm{~s}^{-1}$ at night and maximum net release rates were $+0.074 \mathrm{nmol} \mathrm{O}_{2} \mathrm{~cm}^{-2} \mathrm{~s}^{-1}$ during the day (Fig. 4). Although the supernatant water was only saturated $\left(100 \% \approx 105 \mu \mathrm{mol}^{-1}\right.$ at $21^{\circ} \mathrm{C}$ ) for a few hours during late afternoon, gas bubbles developed at or reached the sediment surface, where they may have caused an underestimation of gas exchange at the sediment-water interface. In a follow-up experiment (Expt B2), in which 2 whole cores were again exposed to full and another 2 to ca. $50 \%$ in situ radiation, similar $\mathrm{O}_{2}$ production rates were recorded in all 4 samples, indicating that light is not a limiting factor for $\mathrm{O}_{2}$ release over the sediment-water interface (see also Figs. $3 \& 4$ ). Since the cores used in Expt B1 had rather high pigment concentrations, the biomass-related maximum release rates were very low with 0.11 to $0.25 \mathrm{mg} \mathrm{C} \mathrm{mg} \mathrm{chl} a^{-1} \mathrm{~h}^{-1}$.

Respiration rates of separate gypsum layers ranged from -0.003 to $-0.031 \mathrm{nmol}$ $\mathrm{O}_{2} \mathrm{~cm}^{-2} \mathrm{~s}^{-1}$, which is at the lower range of the values calculated from the microprofiles. The upper orange layer had the highest $\mathrm{O}_{2}$ demand (Fig. 5). Although PFDs were comparatively low at $40 \mu \mathrm{mol}$ photons $\mathrm{m}^{-2} \mathrm{~s}^{-1}$, the 2 layers dominated by Cyanobacteria (upper orange and third blue-green layer) reached positive net production rates of 0.019 and $0.011 \mathrm{nmol}$ $\mathrm{O}_{2} \mathrm{~cm}^{-2} \mathrm{~s}^{-1}$, respectively (Fig. 6). The maximum production rate, measured at $80 \mu \mathrm{mol}$ photons $\mathrm{m}^{-2} \mathrm{~s}^{-1}$, which was the highest possible radiation to be reached with the illumination equipment used, was $0.041 \mathrm{nmol} \mathrm{O}_{2} \mathrm{~cm}^{-2} \mathrm{~s}^{-1}$. This corresponded to ca. $55 \%$ of the maximum rates measured in whole cores during full daylight. In the 2 other layers (white and purple), $\mathrm{O}_{2}$ concentrations also decreased continuously under increasing PFDs, and positive net production rates were never determined. In a follow-up experiment (not shown), the 2 productive layers (orange and blue-green) were enriched with nutrients. Respiration rates were slightly higher with -0.003 to $-0.068 \mathrm{nmol} \mathrm{O}_{2} \mathrm{~cm}^{-2} \mathrm{~s}^{-1}$ and $\mathrm{O}_{2}$ export started at $80 \mu \mathrm{mol}$ photons $\mathrm{m}^{-2} \mathrm{~s}^{-1}$. Biomass-related production rates of all photosynthetic layers amounted to 0.02 to $0.33 \mathrm{mg} \mathrm{C} \mathrm{mg} \mathrm{chl} a^{-1} \mathrm{~h}^{-1}$.

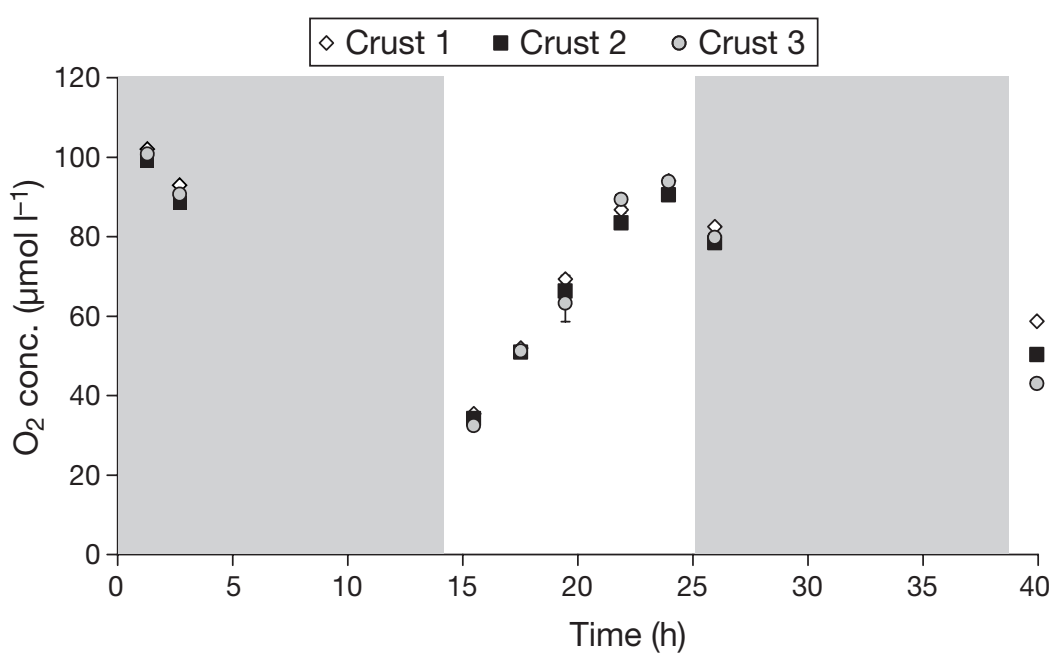

Fig. 3. Oxygen concentration $\left(\mu \mathrm{mol} \mathrm{l} \mathrm{l}^{-1}\right.$ ) in Pond 103 cores at 12 to $15 \mathrm{~cm}^{2}$ and 5 to $6 \mathrm{~cm}$ depth under natural solar radiation at $22^{\circ} \mathrm{C}$ on 3 April (grey: night hours)

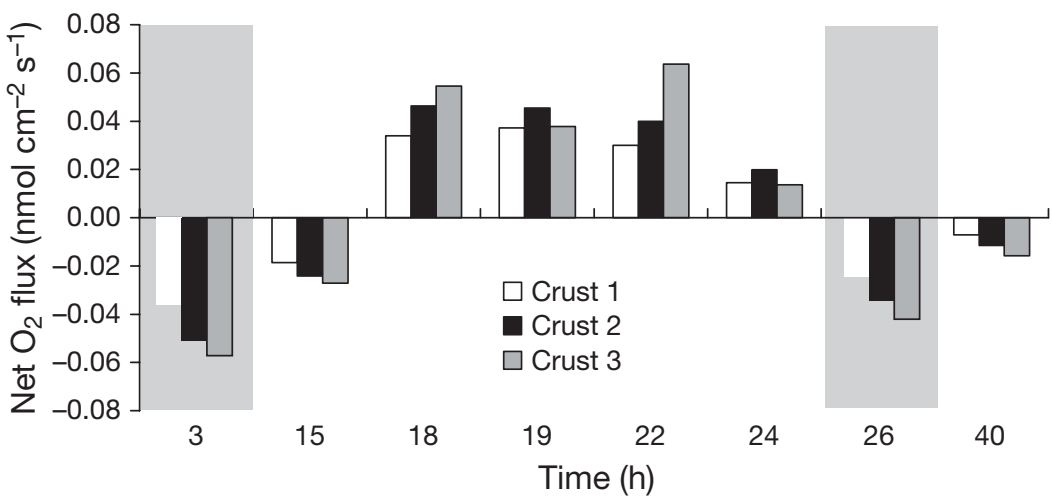

Fig. 4. Net oxygen flux (nmol $\mathrm{O}_{2} \mathrm{~cm}^{-2} \mathrm{~s}^{-1}$ ) over the water-sediment interface calculated from data presented in Fig. 3 (grey: night hours)

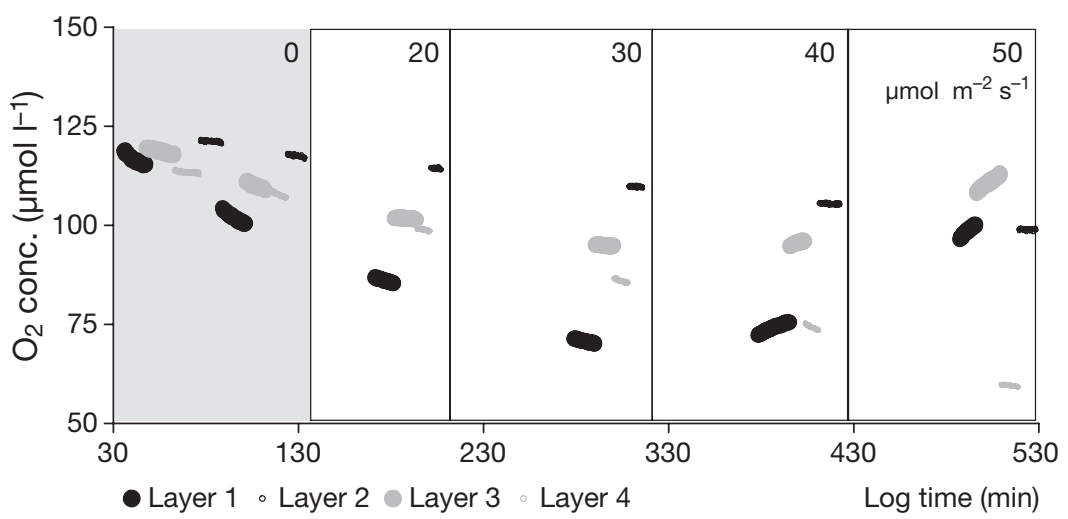

Fig. 5. Development of $\mathrm{O}_{2}$ concentration $\left(\mu \mathrm{mol} \mathrm{l}^{-1}\right)$ on 3 April in 4 separate layers from Pond 103 crust, submersed in ca. $60 \mathrm{ml}$ habitat water, under different photon fluxes $\left(0,20,30,40\right.$ and $80 \mu \mathrm{mol}$ photons $\left.\mathrm{m}^{-2} \mathrm{~s}^{-1}\right)$. 1: orange layer, dominated by Aphanothece/Halothece; 2 : white layer, rich in mucilage; 3 : bluegreen layer, dominated by filamentous Cyanobacteria; 4: purple layer, dominated by purple sulfur bacteria 


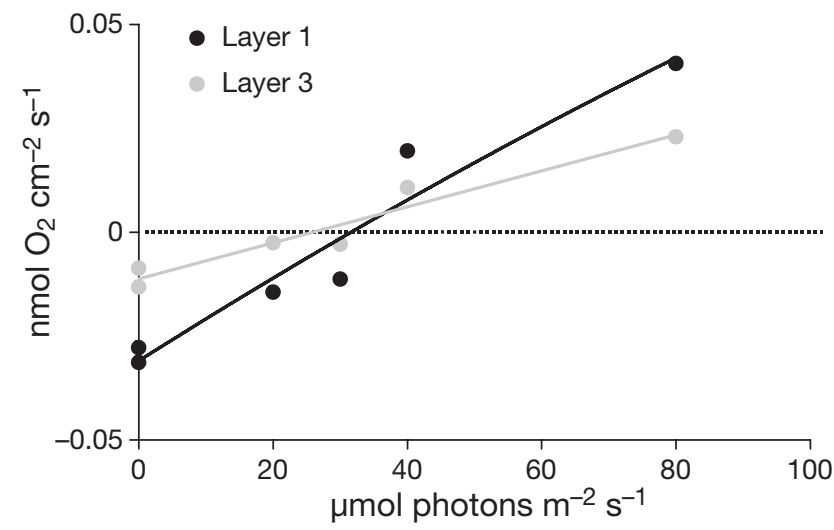

Fig. 6. Net $\mathrm{O}_{2}$ flux (nmol $\left.\mathrm{O}_{2} \mathrm{~cm}^{-2} \mathrm{~s}^{-1}\right)$ in relation to photon flux $\left(\mu \mathrm{mol}\right.$ photons $\mathrm{m}^{-2} \mathrm{~s}^{-1}$ ) in 2 separate autotrophic layers submersed in $50 \mathrm{ml}$ habitat water, calculated from data presented in Fig. 5. 1:

Aphanothece/Halothece; 3: filamentous Cyanobacteria

\section{DISCUSSION}

\section{Microbial community of the gypsum crusts}

The distribution pattern of photosynthetic microorganisms in the mats observed in the salterns of Eilat (Oren et al. 1995, Prášil et al. 2009) was similar to those reported for other mats found in hypersaline environments, e.g. Salins-de-Giraud, France (Caumette et al. 1994) and Guerrero Negro on the Pacific coast of Baja California, Mexico (Rothschild et al. 1994). The occurrence of the (second) white layer is sometimes explained by a local nutrient depletion, where the orange-brown layer absorbs nutrients from the overlying water and the green layer obtains its nutrients from anaerobic degradation processes in the lower layers (Oren et al. 2009). It is unlikely that, in the crusts studied by us, nitrogen was a limiting nutrient because many of the Cyanobacteria present, including some strains of Aphanothece/Halothece, may have fixed $\mathrm{N}_{2}$ (Kohl \& Niklisch 1988). P limitation, in contrast, was indicated by a high phosphatase activity visualised by ELF-Phosphate hydrolysis (cf. Sirová et al. 2006) in the gypsum crusts (data not shown).

The low organic carbon content of the Eilat mats was surprising, because the microbial consortia were so dense that they colored 3 of the 4 layers by their species-specific pigments. The second (white) layer was heavily loaded with mucous material leaking from the severed margins in several centimeters long strands. Thus, the low organic carbon content must be attributable to the large (and heavy) gypsum particles, which do not allow for a large surface area on which microorganisms can settle. Furthermore, the water content of whole cores was low at ca. $20 \%$ and similar to that of medium grain size sandy sediments (Woelfel et al. 2007). Thus, comparisons to other sediments, which are based on sediment mass parameters, are biased. Compared to marine subtidal sediments at a water depth of 0 to $1 \mathrm{~m}$ (cf. Cahoon 1999 and references therein, Woelfel et al. 2007), the pigment content of 56 to $577 \mathrm{mg} \mathrm{chl} \mathrm{a} \mathrm{m}^{-2}$ of the microbial mats in the Eilat gypsum crusts was rather high. Studies from laminated microbial mats (9 $\mathrm{mm}$ depth) of other saltern ponds, e.g. Guerrero Negro (Mexico), found much higher con-

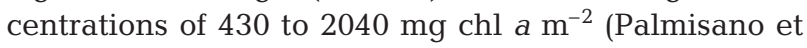
al. 1989). The specific architecture of the crusts allows for considerable biomass colonising deeper layers while receiving sufficient amounts of light. In the upper layers of the crust, scalar irradiance reached up to $200 \%$ of the incident irradiance at the crust surface due to intense scattering (Oren et al. 1995). Even where chl a was found at comparable depths in sandy or silty marine sediments, the $\mathrm{O}_{2}$ evolution wasunlike in the gypsum crusts - usually restricted to the upper $5 \mathrm{~mm}$ because of poor light penetration and a high light absorption by the microphytobenthos living on top of the sediment (Cohen 1989).

\section{$\mathrm{O}_{2}$ production and exchange via the crust surface}

The estimated net $\mathrm{O}_{2}$ release based on in situ microprofiling were in the same range as those obtained by whole core incubations. Differences between the 2 approaches were conspicuous especially during morning measurements. Although negative $\mathrm{O}_{2}$ net production rates were measured in the optode-equipped chambers, positive rates were determined by the microsensor within the mat. It is possible that a small amount of $\mathrm{H}_{2} \mathrm{~S}$ present in the overlying water in the in situ set up had to be chemically reduced first. In a previous report from Pond 200, $\mathrm{O}_{2}$ release rates, based on estimated molecular diffusion from microprofiling, were also consistent with results of benthic chamber incubations (Canfield et al. 2004). Since the amount of available data is very limited and the general problems with spatial heterogeneity mentioned above are considerable, further comparisons of the net $\mathrm{O}_{2}$ release rates measured using the 2 setups are of little relevance.

The rates of dark (night) $\mathrm{O}_{2}$ release measured using the 2 methods differed substantially, with rates of $0.008 \mathrm{nmol} \mathrm{cm} \mathrm{c}^{-2} \mathrm{~s}^{-1}$ estimated from microprofiles and $0.056 \mathrm{nmol} \mathrm{cm} \mathrm{cm}^{-2} \mathrm{~s}^{-1}$ from the whole core incubations. Based on previous evidence from other ponds in the Eilat salterns (Canfield et al. 2004), the estimated rate obtained with the microsensor appears to be very low in the present study. This may also be attributed to spatial heterogeneity, so that more measurements at several other crusts and core incubations will yield a better and more conclusive overview on net $\mathrm{O}_{2}$ release rates during the day and at night. 
Measured microprofiles showed that most of the $\mathrm{O}_{2}$ generated during the day did not escape the crust (Table 3). Both the present and previous studies on the Eilat salterns have indicated that most of the $\mathrm{O}_{2}$ produced in the third (green) layer is retained and consumed within this layer and, therefore, $\mathrm{O}_{2}$ supersaturation does not occur (Canfield et al. 2004). Furthermore, due to $\mathrm{O}_{2}$ consumption by the oxidation of metal sulfides accumulated during the dark period (Wieland et al. 2005), measurements of $\mathrm{O}_{2}$ release rates alone may cause an important underestimation of the net $\mathrm{O}_{2}$ production rate. However, $\mathrm{H}_{2} \mathrm{~S}$ gradients simultaneously measured in the crusts of Pond 103 do not support substantial chemical $\mathrm{O}_{2}$ consumption (Sørensen et al. 2009, this Special Issue). This is interesting from a mass-balance perspective, since it indicates that most of the organic material generated during daytime is already consumed by the following morning. $\mathrm{O}_{2}$ profiles measured during day/night cycles in microbial mats of the Guerrero Negro evaporation ponds (salinity 0.65 to $1.25 \mathrm{mg} \mathrm{ml}^{-1}$ ) have also shown that, during daytime, most of the $\mathrm{O}_{2}$ formed in the mat is recycled locally by respiration of organic carbon (Canfield \& Des Marais 1993). At night, oxidation of sulfide near the mat-water interface was the main $\mathrm{O}_{2}$-consuming process; thus, dissimilatory sulfate reduction is the principal source of dissolved inorganic carbon (DIC) at night. In the Eilat crust, $30 \%$ of the $\mathrm{O}_{2}$ produced during the first half of the light cycle accumulated in the crust (Canfield et al. 2004), compared to less than $1 \%$ in Guerrero Negro, Baja California Sur, Mexico (Canfield \& Des Marais 1993, Des Marais 1995). A careful comparison of the $\mathrm{O}_{2}$ and DIC fluxes across the crust-water interface revealed that, during the day, more inorganic carbon diffuses into the mat than $\mathrm{O}_{2}$ diffuses out (Oren 2009).

The net $\mathrm{O}_{2}$ production rates in the photoautotrophic zones, measured by optode sensor spots, were rather low with $1.4 \mathrm{nmol} \mathrm{O}_{2} \mathrm{~cm}^{-2} \mathrm{~min}^{-1}$ in the orange and $2.5 \mathrm{nmol} \mathrm{O}_{2} \mathrm{~cm}^{-2} \mathrm{~min}^{-1}$ in the green layer (cf. Table 1 in Oren 2009). This may be attributed partly to the maximum photon flux of $80 \mu \mathrm{mol}$ photons $\mathrm{m}^{-2} \mathrm{~s}^{-1}$ applied, an intensity insufficient for maximum net photosynthesis (Fig. 6). In the whole cores of the in situ approach, higher net $\mathrm{O}_{2}$ release rates of $4.4 \mathrm{nmol} \mathrm{O}_{2}$ $\mathrm{cm}^{-2} \mathrm{~min}^{-1}$ were determined, which are comparable to the net production rate of up to $10.8 \mathrm{nmol} \mathrm{O}_{2} \mathrm{~cm}^{-2}$ $\mathrm{min}^{-1}$ measured by Wieland et al. (2005) in the Salins de Giraud, France. This indicates that such exchange rates and, therefore, the laminated mat or crust communities strongly depend on high solar radiation levels. It still remains to be evaluated if and to what extent $\mathrm{O}_{2}$ exchange rates reflect carbon fixation (and biomass growth) when other $\mathrm{O}_{2}$ depletion processes are very high.

\section{Applicability of the benthic chamber setup}

Availability of $\mathrm{O}_{2}$ in hypersaline waters is limited due to the low solubility of $\mathrm{O}_{2}$, which is further diminished by the ambient high temperatures (Sherwood et al. 1991, 1992). Additionally, the $\mathrm{O}_{2}$ release rates, i.e. the net $\mathrm{O}_{2}$ production of the sediment, may be low. Thus, $\mathrm{O}_{2}$ measurements with optodes are recommended for low concentration-change rates. The principle of (benthic) incubation chambers equipped with sensor spots allows a simple determination of $\mathrm{O}_{2}$ exchange over whole cores or net production in slurries without subsampling (Winkler) or chemical $\mathrm{O}_{2}$ consumption (Clark electrodes). Biofilm formation on the spots has not been observed so far, and if it should occur, the spots are easy to clean chemically or by autoclaving. The spots are fairly resistant to drying and have had a long lifetime in our laboratory so far. However, the absence of $\mathrm{O}_{2}$ gradients in the chambers remains to be checked carefully. The chamber approach opens many further possibilities to manipulate whole sediment cores or slurries and to estimate production rates under more controlled radiation conditions. Most often, the respective biomass parameters are available (in contrast to microprofile approaches), e.g. chl a per area, volume or sediment mass, from which microphytobenthos productivity, e.g. as $\mathrm{O}_{2}$ evolution per biomass unit, can be estimated. $\mathrm{O}_{2}$ productivity per biomass unit is a valuable parameter to compare different microphytobenthic communities. Of course, extrapolation of such results to in situ conditions must be done with great care.

Acknowledgements. This study was carried out during the 8th International Workshop of Group for Aquatic Primary Productivity (GAP) and Batsheva de Rothschild Seminar on Gross and Net Primary Productivity held at the Interuniversity Institute for Marine Sciences, Eilat, Israel in April 2008. We thank the Batsheva de Rothschild Foundation, Bar Ilan University, the Moshe Shilo Center for Marine Biogeochemistry, and the staff of the Interuniversity Institute for funding and logistic support. Further financial support was also received from the Deutsche Forschungsgemeinschaft (Schu 965/7-1, Wa 2723/1-1) and the FAZIT Foundation (for J.W.). We also thank the Israel Salt Company in Eilat, Israel for allowing access to the salterns.

\section{LITERATURE CITED}

Cahoon LB (1999) The role of benthic microalgae in neritic ecosystems. Oceanogr Mar Biol 37:47-86

Cahoon LB, Cooke JE (1992) Benthic microalgal production in Onslow Bay, North-Carolina, USA. Mar Ecol Prog Ser 84: 185-196

Canfield DE, Des Marais DJ (1993) Biogeochemical cycles of carbon, sulfur, and free oxygen in a microbial mat. Geochim Cosmochim Acta 57:3971-3984

Canfield DE, Sørensen K, Oren A (2004) Biogeochemistry of a gypsum-encrusted microbial ecosystem. Geobiology 2: $133-150$ 
Caumette P, Matheron R, Raymond N, Relexans JC (1994) Microbial mats in the hypersaline ponds of Mediterranean Salterns (Salins-De-Giraud, France). FEMS Microbiol Ecol 13:273-286

Cohen Y (1989) Photosynthesis in cyanobacterial mats and its relation to the sulfur cycle: a model for microbial sulfur interactions. In: Cohen Y, Rosenberg E (eds) Microbial mats: physiological ecology of benthic microbial communities. Am Soc Microbiol, Washington DC, p 22-36

Coleman MU, White MA (1993) The role of biological disturbances in the production of solar salt. In: Kahihana $H_{\text {, }}$ Hardy HR Jr, Toyikura K (eds) Seventh symposium on salt, Vol I. Elsevier, Amsterdam p 623-631

Des Marais DJ (1995) The biogeochemistry of hypersaline microbial mats. In: Jones JG (ed) Advances in microbial ecology, Vol. 14. Plenum Press, New York, p 251-274

Garcia-Pichel F, Nübel U, Muyzer G (1998) The phylogeny of unicellular, extremely halotolerant Cyanobacteria. Arch Microbiol 169:469-482

Garside C, Garside JC (1993) The 'f-ratio on $20^{\circ} \mathrm{W}$ during the North Atlantic Bloom Experiment. Deep-Sea Res 2:75-90

Glud RN (2008) Oxygen dynamics of marine sediments. Mar Biol Res 4:243-289

Glud RN, Kühl M, Kohls O, Ramsing NB (1999) Heterogeneity of oxygen production and consumption in a photosynthetic microbial mat as studied by planar optodes. J Phycol 35:270-279

Glud RN, Eyre BD, Patten N (2008) Biogeochemical responses to mass coral spawning at the Great Barrier Reef: effects on respiration and primary production. Limnol Oceanogr 53:1014-1024

Hillebrand H (1999) Effects of biotic interactions on the structure of microphytobenthos. PhD Thesis, University of Kiel

Ionescu D, Lipski A, Altendorf K, Oren A (2007) Characterization of the endoevaporitic microbial communities in a hypersaline gypsum crust by fatty acid analysis. Hydrobiologia 576:15-26

Jeffrey SW, Humphrey GF (1975) New spectrophotometric equations for determining chlorophylls $a, b, c_{1}$ and $c_{2}$ in higher plants, algae and natural phytoplankton. Biochem Physiol Pflanz 167:191-194

Kohl JG, Niklisch A (1988) Ökophysiologie der Algen. Wachstum und Ressourcennutzung. Akademie-Berlag, Berlin

Kühl M, Polerecky L (2008) Functional and structural imaging of phototrophic microbial communities and symbioses. Aquat Microb Ecol 53:99-118

Kühl M, Glud RN, Ploug H, Ramsing NB (1996) Microenvironmental control of photosynthesis and photosynthesis-coupled respiration in an epilithic cyanobacterial biofilm. J Phycol 32:799-812

Lindell D, Post AF (1995) Ultraphytoplankton succession is triggered by deep winter mixing in the Gulf of Aqaba (Eilat), Red Sea. Limnol Oceanogr 40:1130-1141

Longphuirt SN, Clavier J, Grall J, Chauvaud L and others (2007) Primary production and spatial distribution of subtidal microphytobenthos in a temperate coastal system, the Bay of Brest, France. Estuar Coast Shelf Sci 74: $367-380$

> Oren A (2009) Saltern evaporation ponds as model systems for the study of primary production processes under hypersaline conditions. Aquat Microb Ecol 56:193-204

- Oren A, Kühl M, Karsten U (1995) An endoevaporitic microbial mat within a gypsum crust: zonation of phototrophs, photopigments, and light penetration. Mar Ecol Prog Ser 128:151-159

>ren A, Sørensen KB, Canfield DE, Teske AP, Ionescu D, Lipski A, Altendorf K (2009) Microbial communities and processes within a hypersaline gypsum crust in a saltern evaporation pond (Eilat, Israel). Hydrobiologia 626:15-26

Palmisano AC, Cronin SE, Amelio E, Munoz E, Des Marais D (1989) Distribution and survival of lipophilic pigments in a laminated microbial mat community near Guerrero Negro, Mexico. In: Cohen Y, Rosenberg E (eds) Microbial mats, physiological ecology of benthic microbial communities. American Society for Microbiology, Washington, DC, p 138-152

Prášil O, Bína D, Medová H, Reháková K, Zapomělová E, Veselá J, Oren A (2009) Emission spectroscopy and kinetic fluorometry studies of phototrophic microbial communities along a salinity gradient in solar saltern evaporation ponds of Eilat, Israel. Aquat Microb Ecol 56: 285-296

Revsbech NP (1989) An oxygen sensor with a guard cathode. Limnol Oceanogr 24:474-478

Revsbech NP, Sørensen J, Blackburn TH, Lomholt JP (1980a) Distribution of oxygen in marine sediments measured with microelectrodes. Limnol Oceanogr 25:403-411

Revsbech NP, Jørgensen BB, Blackburn TH (1980b) Oxygen in the sea bottom measured with a microelectrode. Science 207:1355-1356

Revsbech NP, Jørgensen BB, Blackburn TH, Cohen Y (1983) Microelectrode studies of the photosynthesis and $\mathrm{O}_{2}, \mathrm{H}_{2} \mathrm{~S}$, and $\mathrm{pH}$ profiles of a microbial mat. Limnol Oceanogr 28:1062-1074

Rothschild LJ, Giver LJ, White MR, Mancinelli RL (1994) Metabolic activity of microorganisms in gypsum-halite crusts. J Phycol 30:431-438

Sherwood JR, Stagnitti F, Kokkinn MJ, Williams WD (1991) Dissolved oxygen concentrations in hypersaline waters. Limnol Oceanogr 36:235-250

Sherwood JR, Stagnitti F, Kokkinn MJ, Williams WD (1992) A standard table for predicting equilibrium dissolved oxygen concentrations in salt lakes dominated by sodium chloride. Int J Salt Lake Res 1:1-6

Sirová D, Vrba J, Rejmánková E (2006) Extracellular enzyme activities in benthic cyanobacterial mats: comparison between nutrient-enriched and control sites in marshes of northern Belize. Aquat Microb Ecol 44:11-20

Solórzano L (1969) Determination of ammonia in natural waters by the phenol hypochlorite method. Limnol Oceanogr 14: 799-801

Sørensen K, Řeháková K, Zapomělová E, Oren A (2009) Distribution of benthic phototrophs, sulfate reducers, and methanogens in two adjacent saltern evaporation ponds in Eilat, Israel. Aquat Microb Ecol 56:275-284

Sørensen KB, Canfield DE, Oren A (2004) Salt responses of benthic microbial communities in a solar saltern (Eilat, Israel). Appl Environ Microbiol 70:1608-1616

Sørensen KB, Canfield DE, Teske AP, Oren A (2005) Community composition of a hypersaline endoevaporitic microbial mat. Appl Environ Microbiol 71:7352-7365

Stihl A, Sommer U, Post AF (2001) Alkaline phosphatase activities among populations of the colony-forming diazotrophic cyanobacterium Trichodesmium spp. (Cyanobacteria) in the Red Sea. J Phycol 37:310-317

Strickland JD, Parsons TR (1972) A practical handbook of seawater analysis, 2nd Ed. Bull Fish Res Board Canada 167

Thomas JC (1984) Formations benthiques à Cyanobactéries des salins de Santa Pola (Espagne): Composition spécifique, morphologie et caractéristiques biologiques des principaux peuplements. Rev Inv Geol 38/39: 139-158 
Verardo DJ, Froelich PN, McIntyre A (1990) Determination of organic carbon and nitrogen in marine sediments using the Carlo Erba NA-1500 Analyser. Deep-Sea Res 37: 157-165

- Warkentin M, Freese HM, Karsten U, Schumann R (2007) New and fast method to quantify plankton community respiration by optical oxygen sensor spots. Appl Environ Microbiol 73:6722-6729

Editorial responsibility: Ilana Berman-Frank, Ramat Gan, Israel
Wieland A, Zopfi J, Benthien M, Kühl M (2005) Biogeochemistry of an iron-rich hypersaline microbial mat (Camargue, France). Microb Ecol 49:34-49

> Winkler LW (1888) The determination of dissolved oxygen in water. Ber Deutsch Chem Gesell 21:2843-2855

Woelfel J, Schumann R, Adler S, Hübener T, Karsten U (2007) Diatoms inhabiting a wind flat of the Baltic Sea: Species diversity and seasonal succession. Estuar Coast Shelf Sci 75:296-307

Submitted: December 1, 2008; Accepted: May 14, 2009

Proofs received from author(s): July 20, 2009 